\title{
Index rerum ad Vol. 18
}

ABO blood groups and serum acid phospliatase 289

, distribution in Great Nicobar

(India) 147

Ladakhis (India) 78

interaction with Secretor genes 444

Acid phosphatase, serum, relation to ABO

groups 289

- $\quad$ types of red cell, in Denmark 386

, in Iranians 421

, in South-East Asia 45

- $\quad$ variants in cell cultures 409

Agammaglobulinaemia, counselling 539

Amenorrhoea, karyotype-phenotype

correlations 479 American Seneca Indians, genetic studies

251 Anthropological traits in Seneca Indians

251

triplets 496

Asia, South East, acid phosphatase types

45 Bart's haemoglobin in Israel 361 Beta-lipoprotein types 349 Bisalbuminaemia in paternity cases 271 Brazil, haemoglobin variants and gene

flow 449 Cleft lip and palate, family

studies 229 Colour blindness in Great Nicobar (India)

147

Seneca Indians 251

Congenital malformations in Bombay

97, 103 Counselling 521, 534 Denmark, acid phosphoglucomutase types

386 Dermatoglyphics, asymmetry of ridge

counts 599

- $\quad$ in childhood schizophrenia 300

- $\quad$ Seneca Indians 251

Down's syndrome, unusual case 38 Ear lobe attachment types in Mysore

(India) 380

North Indian populations 277

Eskimos, Gc, Gm and Hp types in East

Greenland 61

in West Greenland 261

Esterase types in human sperms 55 Gc-Secretor correlations 475

Gc types and rheumatic fever 399 
- $\quad$ in Greenland Eskimos 61, 261

Glycogen storage disease, type III,

enzyme studies in relatives 128 Gm types in Greenland Eskimos 61, 261

Koreans 468

Goitre, water iodine and PTC tasting

ability 593 Greenland Eskimos, see Eskimos G-6-PD deficiency in Hungary 1

leprosy 159

Seneca Indians 251

Haemoglobin $\mathrm{H}$ disease 12

- $\quad$ variants in Brazil 449

Holland 429

Israel 361

Seneca Indians 251

Haemophilia, counselling 538

Hairy pinnae in India 511

Hand clasping in Indian populations

283, 606 Holland, Haemoglobin variants 429 Hp types in Greenland Eskimos 61, 261

Italy 458

Seneca Indians 251

Spain 155,579

Hungary, G-6-PD deficiency 1

- $\quad$ PTC tasting ability 137

Hunter's syndrome, counselling 530, 539 Hurler's syndrome, counselling 530 Iceland, lactate dehydrogenase variants

553 Inbreeding in Kerala (India) 369 India, blood groups 78, 147

colour blindness 147

congenital malformations 97, 193

ear lobe attachment types 277,380

hand clasping types 283, 606

hairy pinnae 511

mid phalangeal hair 70, 147

PTC tasting abüity 145, 147

Sickle cell trait 147

Indians, American, see American Indians Iodine in Water, goitre and PTC tasting

ability 593 Iranians, red cell acid phosphatase types

421 Isoniazid acetylation polymorphism in

monkeys 394 Israel, Haemoglobin Bart’s 361

610

Index rerum

Italy, Hp types 458 Karyotype-phenotype correlations in

amenorrhoea 479

male sex abnormalities 315

Koreans, Gm types 468

Lactate dehydrogenase variants in 
Iceland and Sweden 553 Lens weight and age in cockerels 180 Leprosy and G-6-PD deficiency 159 Linkage studies, PGM and PTC 416, 420 LP types 349 Malformations, congenital, in India 97, 193 Mental retardation, family studies 206 Mid phalangeal hair in India 70, 147 MNS blood groups in Ladakhis (India) 78 Morphogenetic homeostasis 341 Muscular dystrophy, x-linked, counselling

536 Non-linear regression analysis 180 Phosphoglucomutase types in Denmark

386 -, new variant 123

416, 420

and PTC tasting ability, linkage study

Phosphogluconate dehydrogenase

variants 109 Placental alkaline phosphatase, variant

543 Pseudocholinesterase, atypical gene in

different populations 567

- $\quad$ fluoride resistant gene in Britain 563

- $\quad$ variants, differentiation by alkyl alco

hols 325, 335

sodium chloride 556

PTC tasting ability and phosphoglucomutase, linkage study 416, 420

in Hungary 137

India 145, 147

psychiatric patients 31

, water iodine and goitre 593

Red cell acid phosphatase types, see Acid

phosphatase Regression analysis, non-linear $180 \mathrm{Rh}$ blood groups in Ladakhis (India) 78

Rheumatic fever and Gc types 399 Schizophrenia of childhood,

dermatoglyphics 300 -, PTC taste ability in 31 Secretor-ABO interaction 444

- $\quad$ Gc correlations 475

Serum proteins in twins 23

Serum types, see Gc, Gm, Hp, Lp and Tf

types Sickle cell trait in Great Nicobar (India)

147 Spain, Hp types 155, 579 Sperms, esterase types 55 Spikes, 14 and 6 per second positive, family studies 163 Statistical inference 84 Sweden, LDH variants 553 Transferrin B variant 573 - $\quad$ types in Seneca Indians 251

Translocation (C/D), familial 241

Triplets, anthropological traits 496

Trisomy of chromosome no. 3584

Turner's syndrome, unusual case 487

Twins, serum proteins 23

Twin studies, methods of analysis 170 